Bulletin of Pharmaceutical Sciences
Assiut University

\title{
STIMULATION OF MELANOGENESIS BY POLYPHENOLIC COMPOUNDS FROM CITHAREXYLLUM QUADRANGULARE IN B16F1 MURINE MELANOMA CELLS
}

\author{
Ahmed E. Allam* \\ Department of Pharmacognosy, Faculty of Pharmacy, Al-Azhar University, Assiut Branch, \\ Assiut 71524, Egypt
}

Two polyphenolic compounds; 1,3,6-tri-O-galloyl- $\beta$-D-glucopyranose (TGG) (1) and methyl gallate (2) have been isolated from the aerial parts of Citharexylum quadrangulare Jacq. They were isolated for the first time from the genus Citharexylum and their structures have been established on the basis of spectroscopic methods in addition to comparison with literature data. The stimulatory activity of the isolated compounds was investigated on melanin synthesis where they stimulate the intracellular synthesis of melanin in murine melanoma B16F1 cells in cultured cell lines. The melanin content was dramatically increased by these compounds in a dose dependent manner and at nontoxic concentrations where $I_{50}$ of TGG was $20.4 \mu \mathrm{M}$ and that of methyl gallate was $16.1 \mu \mathrm{M}$. Moreover, the isolated compounds were tested for cytotoxic activity where $I C_{50}$ of compounds (1) \& (2) were 1.5 and $10.8 \mu M$, respectively. Also, they exhibited higher radical scavenging activity than ascorbic acid in DPPH assay system with $I_{50}$ of 1.5 and $10.8 \mu M$ for compounds (1) \& (2) respectively. Dramatic stimulatory effect of the isolated compounds on melanogenesis might be applied to various conditions of hypopigmentation-related disorders like Vitiligo as an adjunctive therapy in addition to its safely use as an antioxidant. The obtained results indicated that these active compounds could be used safely in cosmetic purposes.

\section{INTRODUCTION}

Genus Citharexylum of family Verbenaceae includes about 115 species. Citharexylum quadrangulare Jacq. is cultivated in Egypt as a street tree and is a popular ornamental in many tropical and subtropical regions. The plant is usually branching from the base and attains up to 6-7 $\mathrm{m}$ in height. The stem is covered with a grayish bark and dotted with numerous lenticels; branch lets slightly quadrangular, brownish and glabrous. Leaves are simple and opposite. The racemes are drooping, simple or branched at the base and up to $30 \mathrm{~cm}$ long. The flower is functionally unisexual and the trees are dioecious. The flowering season is from March to May followed by the fruiting season to the end of May $^{1 \& 2}$.

Received in 19/11/2014 \& Accepted in 31/12/2014

*Corresponding author: Ahmed E. Allam, E-mail: aallam81@yahoo.co.uk
The plant has been used in folk medicine as diuretic, antipyretic, antiarthritic and in liver disorders ${ }^{2}$. Also, it possesses a wide range of pharmacological actions such as the antibacterial activity against multidrug-resistant uropathogens and as diuretic ${ }^{3}$. Besides, it is used for the treatment of urinary tract infections. Moreover, it is useful in treatment of various diseases such as decoction of young twigs to treat thrush in babies and decoction of bark for treating colds ${ }^{4-6}$. The leaves are used as a source of anthelmintic, antiallergic and antiarthritic drugs $^{7 \& 8}$.

Biological screening of the $70 \%$ aqueous ethanolic extract of $C$. quadrangulare revealed significant antiulcer, antihypertensive and hepatoprotective effects ${ }^{9}$. The chloroformic extract of the plant was found to have potent nephroprotective and antioxidant properties in carbon tetrachloride $\left(\mathrm{CCl}_{4} ; 20 \%\right.$ in olive oil, 2 
$\mathrm{ml} / \mathrm{kg}$ body weight) treated Sprague-Dawley male rats ${ }^{10}$. However, the effects of Citharexylum quadrangulare Jacq. aerial parts constituents on melanogenesis and inflammation (which occur as a result of dermatological diseases) have not been studied at all and hence, the ability of the plant constituents to stimulate melanin synthesis in a murine melanoma cell line was investigated.

Recently, although most polyphenols including gallic acid have an inhibitory effect on melanogenesis in $\mathrm{B} 16 \mathrm{~F} 1$ cells $^{11}$, this study showed that TGG was effective as inducer of melanogenesis at non-toxic concentrations. In this study, the mechanism of galloyl compounds effect on melanogenesis was investigated at a cellular level using B16F1 murine melanoma cells.

Several members of the Verbenaceae are known to contain flavonoids and essential oils. They also contain iridoids, anthocyanins, quinones and caffeic acid derivatives, while alkaloids appear to be rare $^{12}$. A survey of the current literatures revealed the isolation and identification of iridoid glycosides, phlomiol, 5-deoxy pulchelloside, durantoside and lamidoside from the plant of this study ${ }^{12}$. Stigmasterol and oleanolic acid in addition to cirsimaritin and cirsiliol 4'-O- $\beta$-Dglucopyranoside and other flavone glycosides were also reported from the plant ${ }^{13}$.

The present study deals with the isolation and identification of two polyphenoilc compounds $\quad 1,3,6$-tri- $O$-galloyl- $\beta$-D-glucopyranose (TGG) (1) and methyl gallate (2) which were reported here for the first time in the genus Citharexylum. Furthermore, the stimulatory effect of the isolated compounds on melanogenesis in addition to cytotoxicity and antioxidant activities using the in-vitro bioassay were investigated.

\section{EXPERIMENTAL}

\section{General experimental procedures}

${ }^{1} \mathrm{H}-\mathrm{NMR}(400 \mathrm{MHz})$ and ${ }^{13} \mathrm{C}-\mathrm{NMR}(100$

$\mathrm{MHz}$ ) spectra were measured on a JEOL GSX400 spectrometer in $\mathrm{CD}_{3} \mathrm{OD}$. Reversedphase high-performance chromatography experiments were undertaken on ODS columns (particle size: $5 \mu \mathrm{m}$, TOSO, $18 \times 250 \mathrm{~mm}$ ) RP23 (5 $\mu \mathrm{m}$, Waters). Diaion HP-20 (Mitsubishi, Tokyo, Japan), silica gel (63-210 $\mu \mathrm{m}$, Kanto
Kagaku) and ODS (63-212 $\mu \mathrm{m}$, Wako Pure Chemical, Tokyo, Japan) were used for open column chromatography. Thin-layer chromatography (TLC) was carried out on silica gel $\left(\mathrm{SiO}_{2}, 60-100\right.$ mesh; Wako Pure Chemical) $60 \mathrm{~F}_{254}$ and RP-18 $\mathrm{F}_{254 \mathrm{~S}}$ (Merck). Structural assignments were based on spectra resulting from one or more of the NMR experiments; ${ }^{1} \mathrm{H}-,{ }^{13} \mathrm{C}-\mathrm{NMR}$, HMQC and HMBC. Fast Atom Bombardment spectrum was carried out on JEOL Mstation while Electron Impact mass spectrum was operated on JEOL JMS SX-102A mass spectrometer.

\section{Plant material}

Air-dried Citharexylum quadrangulare Jacq. (Verbenaceae) aerial parts were collected in May 2009 from Faculty of Agriculture Garden, Assiut University, Assiut City, Egypt. The plant was identified and authenticated by Prof. Dr. A. Fayed, Professor of Plant Taxonomy, Faculty of Science, Assiut University.

\section{Extraction and isolation}

Air-dried Citharexylum quadrangulare Jacq. aerial parts $(4 \mathrm{Kg})$ was extracted thrice with $\mathrm{MeOH}$ (5 L of each) at room temperature. The extracts were combined and filtered through filter paper (Advantec MFS Incorporated). The extracts were removed under reduced pressure using rotary evaporator at $40^{\circ} \mathrm{C}$ to yield the methanol extract $(550 \mathrm{mg})$ which was mixed with distilled water and partitioned between chloroform, ethyl acetate and $n$-butanol ( $5 \mathrm{~L}$ each) to give the chloroform fraction (192 g), ethyl acetate fraction (75 g), $n$-butanol fraction $(85 \mathrm{~g})$ and the rest aqueous fraction $(190 \mathrm{~g})$. The ethyl acetate fraction was in turn partitioned between (methanol-water $90 \%$ ) and $n$-hexane to give $90 \%$ methanol fraction $(52 \mathrm{~g})$ and $n$-hexane fraction (19 g). All fractions were screened for the melanogenesis where noticed that the $n$-butanol fraction is the most active fraction and hence the $n$-butanol fraction (85 g) was subfractionated on Diaion HP-20 column using water and methanol $(25 \%, 50 \%, 75 \%$ and $100 \%$ ) (2 L of each).

The fraction of 50\% methanol-eluted (34.4 g) was further separated by chromatography on ODS column $(80 \times 200 \mathrm{~mm})$ using mobile phase systems of methanol : $\mathrm{H}_{2} \mathrm{O}(20,40,50,60,70$ 
and $90 \% \mathrm{v} / \mathrm{v}$; elution volume: $1.5 \mathrm{~L}$ of each) to give six corresponding fractions. The biologically active fraction eluted with $60 \%$ methanol $(5.2 \mathrm{~g})$ was further fractionated using silica gel column chromatography and eluted stepwise with Chloroform-Methanol (ratios of 9:1, 6:1, 4:1, 3:1 and 1:1, v/v fractions $200 \mathrm{~mL}$ of each) were collected and concentrated to give five corresponding fractions (I-V). $160 \mathrm{mg}$ from the fraction II was further fractionated by preparative HPLC (ODS column: TOSO, 18 $\mathrm{mm} \times 250 \mathrm{~mm}$, particle size: $5 \mu \mathrm{m}$, flow rate: 3 $\mathrm{mL} / \mathrm{min})$ equipped with $\mathrm{UV}$ detector $(210 \mathrm{~nm})$, the mobile phase was $20 \% \mathrm{CH}_{3} \mathrm{OH}$ in $\mathrm{H}_{2} \mathrm{O}$ which resulted in elution of compound (1). The preparative HPLC conditions were also used to separate components of fraction III giving compound (2) (Fig. 1).

These compounds were identified as 1,3,6tri- $O$-galloyl- $\beta$-D-glucopyranose (TGG) (1) and 3,4,5-trihydroxy-benzoic acid methyl ester (2) which were reported here for the first time in the genus by comparison of their spectral data with those reported in literatures ${ }^{14 \& 15}$ (Table 1).

\section{Cell Culture and Melanin content measurement}

B16F1 murine melanoma cells ${ }^{16 \& 17}$ were cultured in DMEM (Dulbecco's Modified Eagle Medium) containing $10 \%$ fetal bovine serum, $0.1 \mathrm{mg} / \mathrm{ml}$ streptomycin, $0.5 \mathrm{mg} / \mathrm{ml} \mathrm{L-}$ glutamate at $37^{\circ} \mathrm{C}$ in a humidified $95 \%$ air $/ 5 \%$ $\mathrm{CO}_{2}$ atmosphere. Cells $\left(5 \times 10^{4}\right.$ cells $\left./ \mathrm{mL}\right)$ were seeded on 24-well plates and incubate for 24 hrs. After incubation, $50 \mu \mathrm{L}$ of galloyl compounds were added (in 2\% DMSO in medium) and $50 \mu \mathrm{L}$ of $\alpha$-MSH (melanin stimulating hormone) $(100 \mathrm{ng} / \mathrm{mL})$. The cells were incubated three days later and the melanin content was measured at $475 \mathrm{~nm}$ absorbance. The intracellular melanin content in cultured $\mathrm{B} 16 \mathrm{~F} 1$ melanoma cells was determined as described by (Hill et al. $)^{18}$ where cells were passed once a week and used between passages N.O. 5 and 8.

Briefly, cultured B16F1 mouse melanoma cells were trypsinized $(0.25 \%$ trypsin and $0.1 \%$ ethylenediamine tetra-acetic acid [EDTA] at $37^{\circ} \mathrm{C}$ for $\left.5-10 \mathrm{~min}\right)$. Cells $\left(2.5 \times 10^{4}\right.$ cells/well in $980 \mu \mathrm{L}$ DMEM) were inoculated with a pipette into 24-well plates and incubated for $24 \mathrm{hrs}$ at $37^{\circ} \mathrm{C}$ in a $\mathrm{CO}_{2}$ incubator. After $24 \mathrm{hrs}$ incubation, $20 \mu \mathrm{L}$ of sample solution were added to each well and the 24-well plate incubated for 2 days at $37^{\circ} \mathrm{C}$ in a $\mathrm{CO}_{2}$ incubator. Each sample was tested in triplicate. Test samples (purity $>93 \%$ ) and the theophylline was dissolved in DMSO/PBS and then diluted with DMEM to achieve the appropriate concentrations. The final concentration of DMSO was $0.03 \%$. In the control group, DMSO/PBS (1:1, v/v) solution diluted with DMEM to $0.03 \%$ of the final DMSO concentration was used instead of the sample solution.

Kojic acid $(100 \mu \mathrm{M})$ was used (purity 90\%; Sigma-Aldrich) as the reference compound $^{18}$ for inhibition of melanogenesis (as an indication for the positive results). After incubation, the effect of both compounds $\mathbf{1}$ and 2 on intracellular melanogenesis in cultured $\mathrm{B} 16 \mathrm{~F} 1$ cells was investigated.

The culture medium was removed with a pipette and assayed for extracellular melanin where the remaining melanoma cells were trypsinized $(0.25 \%$ trypsin and $0.1 \%$ EDTA at $37^{\circ} \mathrm{C}$ for $5-10 \mathrm{~min}$ ) and washed with $100 \mu \mathrm{L}$ PBS. Cells were digested by the addition of $400 \mu \mathrm{L} 1 \mathrm{~N} \mathrm{NaOH}$ and left standing for $16 \mathrm{hrs}$ at room temperature.

The optical density of the resulting solution was measured at $475 \mathrm{~nm}$ and the amount of intracellular melanin was calculated. The culture medium was centrifuged (600 rpm for $10 \mathrm{~min}$ at $4^{\circ} \mathrm{C}$ ) and the aliquot of the supernatant $(1 \mathrm{~mL})$ was added to $1 \mathrm{~mL}$ of a mixture of 0.4 M 2-[4-(2-hydroxyethyl)-1piperazinyl] ethane sulfonic acid (HEPES) buffer (pH 6.8) and ethanol (9:1, v/v) where the optical density of the resulting solution was measured at $475 \mathrm{~nm}$.

\section{Cytotoxicity (MTT) assay}

This method is a colorimetric assay for assessing cell viability ${ }^{19}$. To determine the cytotoxic activity of the tested samples, THP-1 cells $(180 \mu \mathrm{L})$ were seeded in 96-well plates at $1.0 \times 10^{5}$ cells per well with tested samples (purity > 93\%) $(20 \mu \mathrm{L}$ in DMSO/PBS) at various concentrations. After 48 hrs cultivation, the supernatants were removed, non-adherent cells (THP-1) incubated with the tetrazolium dye; 3-(4,5-dimethylthiazol-2-yl)2,5-diphenyltetrazolium bromide (MTT), 10 $\mu \mathrm{L}, 5 \mathrm{mg} / \mathrm{mL}$ in PBS for $4 \mathrm{hrs}$ and then solubilized with $10 \%(\mathrm{w} / \mathrm{v})$ sodium dodecyl 
sulfate (SDS; in $60 \%[\mathrm{v} / \mathrm{v}]$ dimethyl formamide) solution $(100 \mu \mathrm{L})$ for $18 \mathrm{hrs}$. The absorbance was measured at $570 \mathrm{~nm}$ using a microplate reader and the cytotoxicity calculated by comparing absorbance with that of the non-treated control culture. Cell growth curve was graphed using statistical analysis software (Kaleida Graph version 4.00; Synergy Software) and $\mathrm{IC}_{50}$ values calculated using simple linear regression.

$\mathrm{IC}_{50}$ values were calculated from dose response curves for a $48 \mathrm{hrs}$ drug exposure. Data were obtained through independent measurements of cell density and cell viability by the MTT assays ${ }^{19}$.

A dose - response curve was plotted for each compound and the $\mathrm{IC}_{50}$ value was calculated as the concentration of the test compound resulting in 50\% reduction of optical density compared with the control. The $\mathrm{IC}_{50}$ values of the tested samples were calculated using the same software. Differences were considered significant at $p<0.005$.

\section{DPPH radical scavenging activity}

DPPH assay was performed by a method previously reported by (Kumar et al. $)^{20} .100 \mu \mathrm{L}$ of the tested samples at different concentrations in $\mathrm{MeOH}$ and $1.0 \times 10^{-4} \mathrm{M}$ DPPH (Wako) (Tokyo, Japan) in $\mathrm{MeOH}$ (300 $\mu \mathrm{L})$ were added to 96 -well microtiter plate. The plate was shaken for $1 \mathrm{~min}$ on a plate shaker and incubated for $30 \mathrm{~min}$ at room temperature in the dark. After incubation, the absorbance was recorded at $517 \mathrm{~nm}$. The tested samples at different concentrations without DPPH solution were used as a blank control to eliminate the influence of sample color. Ascorbic acid was used as a positive control ${ }^{20}$ and DPPH solution in $\mathrm{MeOH}$ served as a negative control.

\section{Data analysis}

Ratio (percentage of control) of DPPH was determined as mean \pm SD. Statistical significance was determined by Dunnett's multiple test after one-way analysis of variance (ANOVA) with comparison to a control group using statistical analysis software (Kaleida Graph ver. 4.00). Differences were considered significant at $\mathrm{p}<0.05$.

\section{RESULTS AND DISCUSSION}

\section{Results}

Compound 1: Obtained as yellow amorphous powder (34 mg). ${ }^{1} \mathrm{H}-\mathrm{NMR}$ (400, $\left.\mathrm{MHz}, \mathrm{CD}_{3} \mathrm{OD}\right)$ and ${ }^{13} \mathrm{C}$-NMR (100 MHz, $\left.\mathrm{CD}_{3} \mathrm{OD}\right)$ (Table 1). FAB MS at $m / z: 635[\mathrm{M}-\mathrm{H}]^{-}\left(\mathrm{C}_{27} \mathrm{H}_{24} \mathrm{O}_{18}\right)$.

Compound 2: Obtained as yellow amorphous powder $(13 \mathrm{mg}) .{ }^{1} \mathrm{H}-\mathrm{NMR}\left(400, \mathrm{MHz}, \mathrm{CD}_{3} \mathrm{OD}\right)$ and ${ }^{13} \mathrm{C}-\mathrm{NMR}\left(100 \mathrm{MHz}, \mathrm{CD}_{3} \mathrm{OD}\right)$ (Table 1). EI-MS at $m / z: 184\left(\mathrm{C}_{8} \mathrm{H}_{8} \mathrm{O}_{5}\right)$.

\section{Discussion}

The aerial parts of Citharexylum quadrangulare Jacq. were extracted with methanol and then fractionated with $\mathrm{CHCl}_{3}$, EtOAc, $n-\mathrm{BuOH}$ and $\mathrm{H}_{2} \mathrm{O}$. By using combined chromatographic separation of the $n-\mathrm{BuOH}$ fraction, two polyphenolic compounds (1) and (2) (Fig. 1) were isolated.

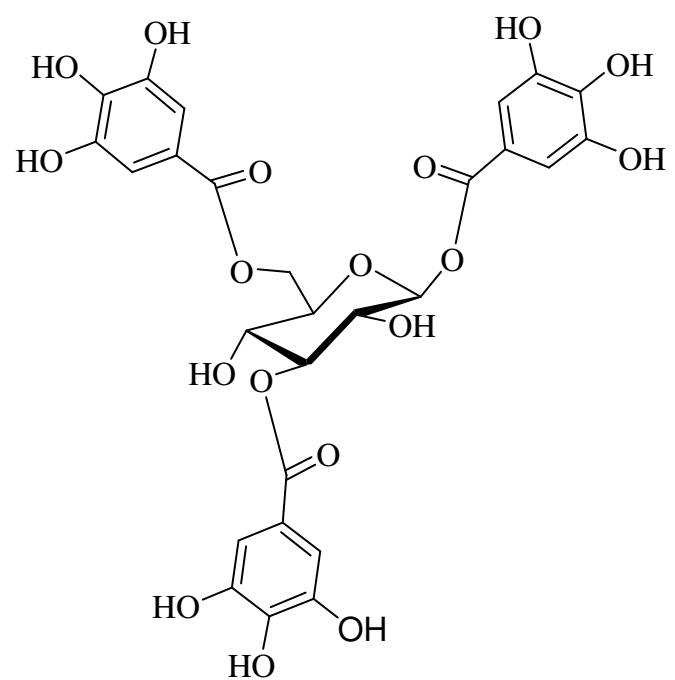

Compound 1<smiles>COC(=O)c1cc(O)c(O)c(O)c1</smiles>

Compound 2

Fig. 1: Structure of compounds (1) and (2). 
Table 1: ${ }^{1} \mathrm{H}$ - and ${ }^{13} \mathrm{C}-\mathrm{NMR}$ assignments for compounds 1, $2\left(\mathrm{CD}_{3} \mathrm{OD}, 400,100 \mathrm{MHz}\right)$.

\begin{tabular}{||c|c|c|c|c|c||}
\hline \multicolumn{3}{|c|}{ Compound 1 } & \multicolumn{3}{c|}{ Compound 2 } \\
\hline No. & ${ }^{1} \mathrm{H}-\mathrm{NMR}$ & & & & \\
\hline Glc & & & & & \\
\hline 1 & $5.75(1 \mathrm{H}, \mathrm{d}, J=8.2 \mathrm{~Hz})$ & 95.86 & 1 & - & 121.40 \\
\hline 2 & $3.71(1 \mathrm{H}, \mathrm{dd}, J=9.3,8.2 \mathrm{~Hz})$ & 72.61 & 2,6 & $7.03(2 \mathrm{H}, \mathrm{s})$ & 110.00 \\
\hline 3 & $5.2(1 \mathrm{H}, \mathrm{t}, J=9.3 \mathrm{~Hz})$ & 78.89 & 3,5 & - & 146.47 \\
\hline 4 & $3.72(1 \mathrm{H}, \mathrm{t}, J=9.3 \mathrm{~Hz})$ & 69.69 & 4 & - & 139.74 \\
\hline 5 & $3.79(1 \mathrm{H}, \mathrm{ddd}, J=9.3,4.8,1.7 \mathrm{~Hz})$ & 77.61 & & & \\
\hline 6 & $6 \mathrm{a}: 4.37(1 \mathrm{H}, \mathrm{dd}, J=12.0,4.8 \mathrm{~Hz})$ & 64.20 & & & \\
\hline & $6 \mathrm{~b}: 4.52(1 \mathrm{H}, \mathrm{dd}, J=12.0,1.7 \mathrm{~Hz})$ & & & & 166.12 \\
\hline 1-Gall & & & $\mathrm{C}=\mathrm{O}$ & - & 52.27 \\
\hline 1 & - & 121.23 & $\mathrm{OCH}$ & $3.80(3 \mathrm{H}, \mathrm{s})$ & \\
\hline 2,6 & $7.08(2 \mathrm{H}, \mathrm{s})$ & 110.36 & & & \\
\hline 3,5 & - & 146.49 & & & \\
\hline 4 & - & 139.91 & & & \\
\hline $\mathrm{C}=\mathrm{O}$ & - & 168.10 & & & \\
\hline 3-Gall & - & & & & \\
\hline 1 & $7.06(2 \mathrm{H}, \mathrm{s})$ & 121.58 & & & \\
\hline 2,6 & - & 110.55 & & & \\
\hline 3,5 & - & 146.52 & & & \\
\hline 4 & - & 140.48 & & & \\
\hline $\mathrm{C}=\mathrm{O}$ & - & 168.20 & & & \\
\hline 6-Gall & - & & & & \\
\hline 1 & - & 120.44 & & & \\
\hline 2,6 & - & 110.17 & & & \\
\hline 3,5 & - & 146.42 & & & \\
\hline 4 & - & 139.79 & & & \\
\hline $\mathrm{C}=\mathrm{O}$ & - & & & & \\
\hline
\end{tabular}

Investigation of ${ }^{1} \mathrm{H}-\mathrm{NMR}$ spectrum of compound 1 (Table 1) concluded the presence of three galloyl moieties attached to one glucose unite which was obvious from the presence of three sets of proton singlet signals at $\delta_{\mathrm{H}} 7.08,7.06$ and 7.02 (each $2 \mathrm{H}, \mathrm{s}$ ) and an anomeric proton signal at $\delta_{\mathrm{H}} 5.75(1 \mathrm{H}, \mathrm{d}, J=$ $8.2 \mathrm{~Hz})$. Moreover, the ${ }^{13} \mathrm{C}-\mathrm{NMR}$ spectrum (Table 1) confirmed the presence of three galloyl groups and one glucose moiety, from the consideration of the sugar carbon chemical shifts as detailed in the literature ${ }^{16}$. The configuration at the glucose $\mathrm{C}-1$ position was concluded to be $\beta$ on the basis of the J-value $(8.2 \mathrm{~Hz})$ of the anomeric proton signal at $\delta_{\mathrm{H}} 5.75$. The site of attachments of each galloyl moiety was confirmed to be at C-1, C-3 and C6 of the glucose unite from the ${ }^{1} \mathrm{H}-,{ }^{13} \mathrm{C}$-NMR downfield shifts at these sites in addition to the 2 DNMR correlations including both HMQC and HMBC experiments. On the basis of the previously mentioned data and by comparison with literature data ${ }^{14}$, compound $\mathbf{1}$ was identified as $1,3,6$-tri- $O$-galloyl- $\beta$-D-glucopyranose (TGG).

The ${ }^{1} \mathrm{H}-\mathrm{NMR}$ spectrum of compound $\mathbf{2}$ (Table 1) exhibited the characteristic signals of methyl gallate by the appearance of a signal at $\delta_{\mathrm{H}} 7.03(2 \mathrm{H}, \mathrm{s}, \mathrm{H}-2,6)$ in addition to a signal at $\delta_{\mathrm{H}} 3.80\left(3 \mathrm{H}, \mathrm{s}, \mathrm{OCH}_{3}\right)$. The ${ }^{13} \mathrm{C}-\mathrm{NMR}$ spectrum (Table 1) revealed the presence of six carbon signals comprising $\mathrm{C}=\mathrm{O}$ signal at $\delta_{\mathrm{c}} 166.12$ (s) indicating the presence of a carbonyl ester, one oxygenated aromatic signal at $\delta_{\mathrm{c}} 139.74$ (C-4), two symmetrical oxygenated aromatic carbon signals at $\delta_{\mathrm{c}} 146.47$ (C-3 and C-5), one quaternary aromatic carbon signal at $\delta_{\mathrm{c}} 121.40$ (C-1), two symmetrical aromatic methane carbon signals at $\delta_{\mathrm{c}} 110.00(\mathrm{C}-2$ and C-6) and one carbon signal at $\delta_{\mathrm{c}} 52.27\left(\mathrm{OCH}_{3}\right)$. Thus, compound 2 was identified as methyl gallate by comparison of these data with those reported in the literature ${ }^{15}$. 


\section{Melanogenesis in B16F1melanoma cells}

In this study, different concentrations ( 0.5 , $1,2,3,4$ and $5 \mu \mathrm{M}$ ) from the two isolated compounds were added to $\mathrm{B} 16 \mathrm{~F} 1$ murine melanoma cells where they stimulate the melanogenesis in this cell line, and this activity may be due to its stimulation of tyrosinase activity (Fig. 2) as in melanogenesis, tyrosinase-related protein-2 and tyrosinaserelated protein-1 catalyzes conversion of DOP achrome to DHICA and oxidation of DHICA, respectively, to form melanin. In the presence of alpha-melanocyte stimulating hormone $(\alpha$ MSH) and isobutylmethylxanthine (IBMX), B16 melanoma cells expressed great amount of tyrosinase and melanin synthesis. $\alpha$-MSH binds to melanocortin receptor (MC1R), resulting in the activation of stimulatory GTP-binding protein (Gs), which in turn, stimulates adenylate cyclase to generate cAMP. cAMP increases melanin synthesis via activation of cAMP-dependent protein kinase (PKA) and microphthalmia-associated transcription factor (MITF), a melanocyte-specific transcription factor, leading to induction of tyrosinase expression. Hyperpigmentation and melasma are the result from the accumulation of tyrosinase and melanin in cells ${ }^{11}$.

The melanin content was dramatically increased by the two isolated compounds in a dose dependent manner and at nontoxic concentrations where $\mathrm{IC}_{50}$ of TGG was 20.4 $\mu \mathrm{M}$ and that of methyl gallate was $16.1 \mu \mathrm{M}$.

Methyl gallate showed nearly no or slight stimulant effect on melanogenesis in contrast to TGG which becomes hydrophilic through the three attached galloyl moieties to the hydrophilic core.
The dramatic stimulatory activity of TGG on melanogenesis against kojic acid as a control $^{18}$ might be applied to various conditions of hypo-pigmentation-related disorders as an adjunctive therapy. It would also be possible to produce effective agents available for such purpose by modification of chemical structure of TGG.

\section{Cytotoxicity (MTT) assay}

The results of cell viability assay using MTT in B16F1 melanoma cells are shown in figure 3 . There was no significant reduction of cell viability after incubation of pigmented B16F1 melanoma cells with both compounds 1 $\& 2$ at different concentrations $(0.5,1,2,3,4$ and $5 \mu \mathrm{M})$ for compound 1 and $(0.5,1,2,3$ and $4 \mu \mathrm{M}$ ) for compound 2 and with $\mathrm{IC}_{50}=20.4$ and $16.1 \mu \mathrm{M}$ for both compounds, respectively. However, the number of viable cells was insignificantly reduced to $90 \%$ at compound $\mathbf{2}$ (Methyl gallate) concentration of $5 \mu \mathrm{M}$. On the other hand, even at very high dosages of both compounds, more than $90 \%$ of $\mathrm{B} 16 \mathrm{~F} 1$ melanoma cells were still viable.

\section{DPPH radical scavenging activity}

In the DPPH assay, the isolated compounds 1 \& 2 at different concentrations $(0.62,1.25,2.5,5$ and $10 \mu \mathrm{M})$ exhibited free radical scavenging activity with $\mathrm{IC}_{50}$ values of 1.5 and $10.8 \mu \mathrm{M}$ for both compounds, respectively. The tested compounds showed strong activities comparing with that of the positive control ascorbic acid (12 $\mu \mathrm{M})$ (Fig. 4).

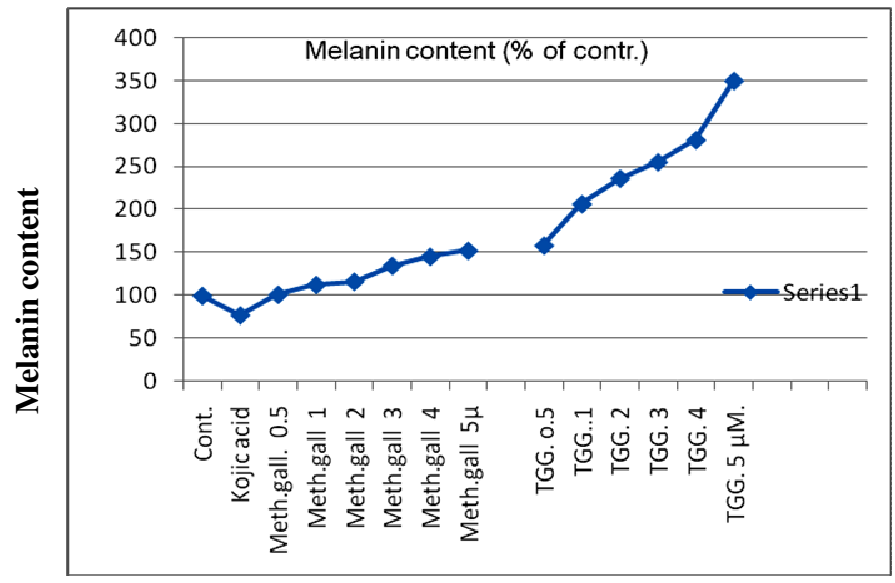

Sample conc. $(\boldsymbol{\mu M}$.

Fig. 2: Melanogenesis in B16F1 melanoma cells. 


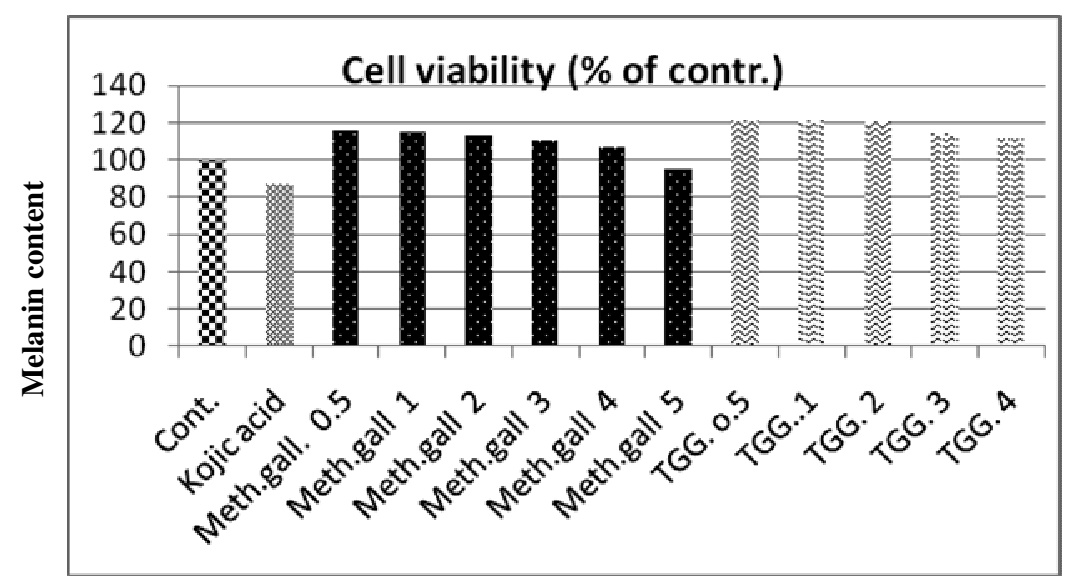

Sample conc. ( $\mu \mathrm{M}$.
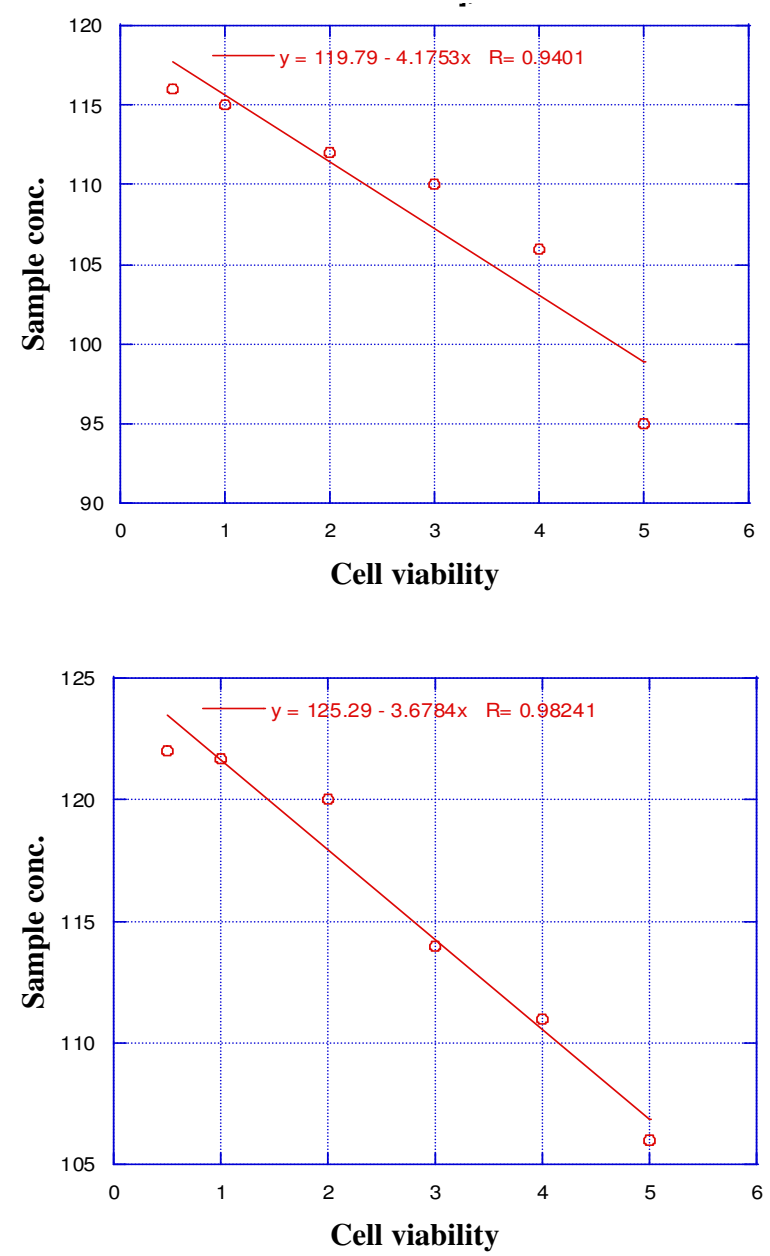

Fig. 3: Cell viability (MTT) assay. 


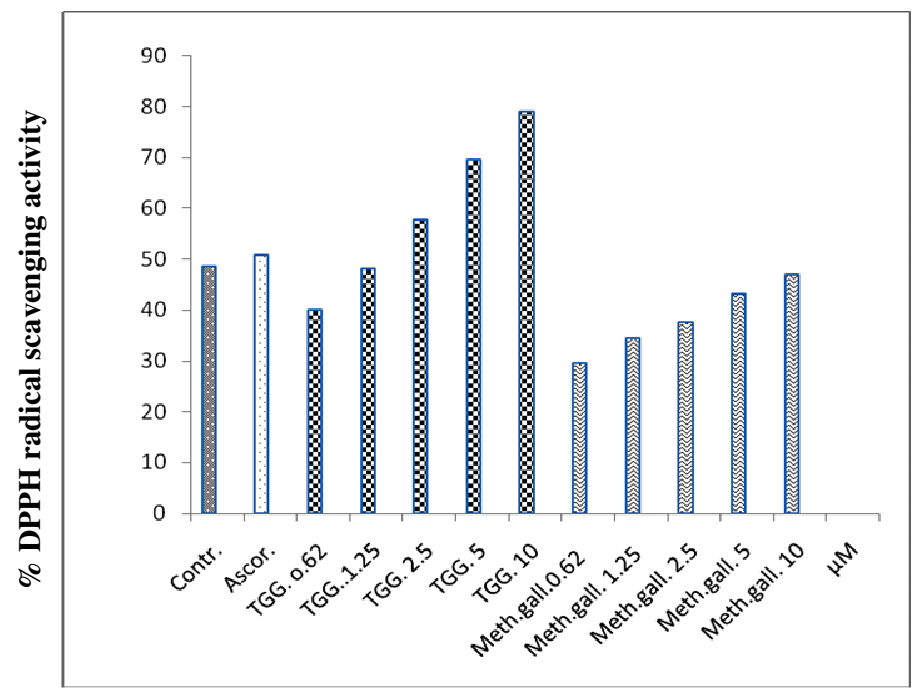

Sample conc. ( $\mu \mathrm{M}$.)
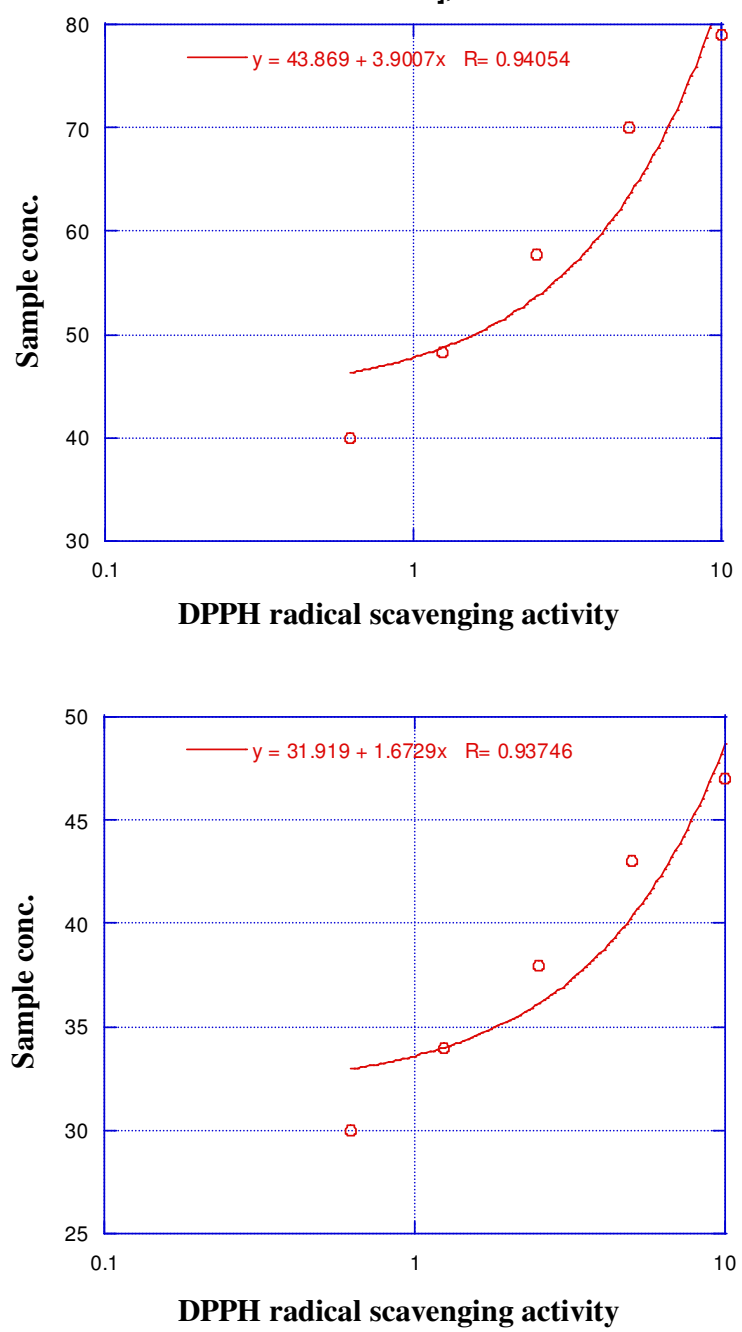

\section{Conclusion}

Fig. 4: DPPH radical scavenging activity of the isolated compounds. 
The melanin content was dramatically increased by the isolated compounds $\mathbf{1}$ and $\mathbf{2}$ in a dose dependent manner and at non-toxic concentrations where $\mathrm{IC}_{50}$ of compound $\mathbf{1}$ (TGG) was $20.4 \mu \mathrm{M}$ and that of compound 2 (methyl gallate) was $16.1 \mu \mathrm{M}$. Both compounds were tested for the cytotoxic activity in MTT assay where $\mathrm{IC}_{50}$ of compounds $1 \& 2$ were 1.5 and $10.8 \mu \mathrm{M}$, respectively and for the antioxidant activity through scavenging effect in the 1,1-diphenyl2-picrylhydrazyl (DPPH) assay where they exhibited higher radical scavenging activity than ascorbic acid in DPPH assay system with $\mathrm{IC}_{50}$ of 1.5 and $10.8 \mu \mathrm{M}$. respectively. Dramatic stimulatory effect of the isolated compounds on melanogenesis might be applied to various conditions of hypo-pigmentation-related disorders like Vitiligo as an adjunctive therapy in addition to their use safely as an antioxidant. These results indicate that these active compounds could be used safely in cosmetic purposes.

\section{Acknowledgment}

This work was supported in part by Pharmacognosy and Chemistry of Natural Products, School of Pharmaceutical Sciences, Kanazawa University, Kanazawa, Japan, for which I am thankful.

\section{REFERENCES}

1- G. H. M. Lawrence, "Taxonomy of Vascular Plants", Oxford and IBH publishing Co., The Macmillan Company, New York, 1951, pp. 686-688.

2- A. N. E. Hamed, M. H. H. Muhammad, H. E. Khalil and M. S. Kamel, "Morphoanatomy studies of the leaf of Citharexylum quadrangulare Jacq. cultivated in Egypt", J. Pharmacog. and Phytoch., 2 (5), 104-109 (2014).

3- A. Bag, S. Bhattacharyya and R. Chattopadhyay, "Isolation and identification of a gallotannin 1,2,6-tri- $O$ galloyl- $\beta$-D-glucopyranose from hydroalcoholic extract of Terminalia chebula fruits effective against multidrug-resistant uropathogens", J. Appl. Microbiol., 115 (2), 390-397 (2013).
4- N. Shalaby and M. Bahgat, "Phytochemical and some biological studies of Citharexylum quadrangulare Jacq.", Chem. Nat. \& Micro. Prod., 4 (10), 219-228 (2003).

5- P. Acevedo-Rodríguez, "Flora of St. John, U.S. Virgin Islands", Mem. New York Bot. Gard., Vol. 78, 1996, pp. 1-581.

6- D. A. Lachman-White, C. D. Adams and U. O. Trotz, "A Guide to the Medicinal Plants of Coastal guyana", Commonwealth Science Council, London, 1987, p. 350.

7- C. Lans, "Comparison of plants used for skin and stomach problems in Trinidad and Tobago with Asian ethnomedicine", $\boldsymbol{J}$. Ethnobiol. Ethnomed., 3 (3), 1-12 (2007).

8- B. Balaázs, G. Tóth, H. Duddeck and H. Soliman, "Iridoid and lignan glycosides from Citharexylum spinosum L.", Nat. Prod. Res., 20 (2), 201-205 (2006).

9- T. I. Khalifa, O. D. El-Gindi, H. A Ammar and D. M. El-Naggar, "Iridoid glycosides from Citharexylum quadrangulare", Asian Journal of Chemistry, 14 (1), 197202 (2003).

10- M. R. Khan and F. Siddique, "Antioxidant effects of Citharexylum spinosum in $\mathrm{CCl}_{4}$ induced nephrotoxicity in rat", Exp. Toxicol. Pathol., 64 (4), 349-355 (2012).

11- K. Tsukamoto, I. J. Jackson, K. Urabe, P. M. Montague and V. J. Hearing, "A second tyrosinase-related protein, TRP-2, is a melanogenic enzyme termed DOPA chrometautomerase", EMBO J., 11 (2), 519-526 (1992).

12- M. A. Hall, "Plant Structure, Function and Adaptation", The English Language Book Society and Macmillan Press Ltd., London and Basingstoke Associated Companies in Delhi, Hong Kong, Lagos and Singapore, 1976, p. 362.

13- M. M. H. Muhammad, A. N. E. Hamed, H. E. Khalil and M. S. Kamel, "A Phytochemical Study of Citharexylum quadrangulare Jacq.", $4^{\text {th }}$ International Scientific Conference of Faculty of Pharmacy, Cairo University "Pharmacy Education and Community Expectations", April $24^{\text {th }}$ and $25^{\text {th }}$ (2013).

14- J. Nicola, H. Terence, H. Edwin and P. Michael, "Multiple interactions between polyphenols and a salivary proline-Rich protein repeat result in complexation and 
precipitation", Biochem., 36 (18), 55665577 (1997).

15- D. Mohd Nazrul Hisham, J. Mohd Lip, J. Mohd Noh, A. Normah and M. F. Nurul Nabilah, "Identification and isolation of methyl gallate as a polar chemical marker for Labisia pumila Benth.", J. Trop. Agric. and Fd. Sc., 39 (2), 279-284 (2011).

16- S. Ho, H. Rho, B. Soo, M. Soo, D. Ahn, K. Hee and S. Ih, "Synthesis of new antimelanogenic compounds containing two molecules of kojic acid", Bull. Korean Chem. Soc., 29 (8), 1569-1571 (2008).

17- D. G. Kim, H. Y. Kim, M. Y. Kim, M. Y. Lee and K. R. You, "Lincomycin abrogates dexamethasone-enhanced melanogenesis in B16F1 melanoma cells", Pigment Cell Res., 11 (3), 143-150 (1998).
18- E. Hill, E. Sarah, B. Jayne, J. Anthony, S. Stanley and M. Shella, "Investigation of the Regulation of pigmentation in $\alpha$ melanocyte-stimulating hormone responsive and unresponsive cultured B16F1 melanoma cells", ibid., 2 (3), 161166 (1989).

19- M. V. Berridge and A. S. Tan, "Characterization of the cellular reduction of 3-(4,5-dimethylthiazol-2yl)-2,5diphenyltetrazolium bromide (MTT): Subcellular localization, substrate dependence, and involvement of mitochondrial electron transport in MTT reduction", Arch. Biochem. Biophys., 303 (2), 474-482 (1993).

20- V. Kumar and M. Mohan, "Physicochemical status and primary productivity of Ana Sagar lake, Ajmer (Rajasthan), India", Univ. J. of Envir. Res. Tech., 1 (3), 286-292 (2011). 


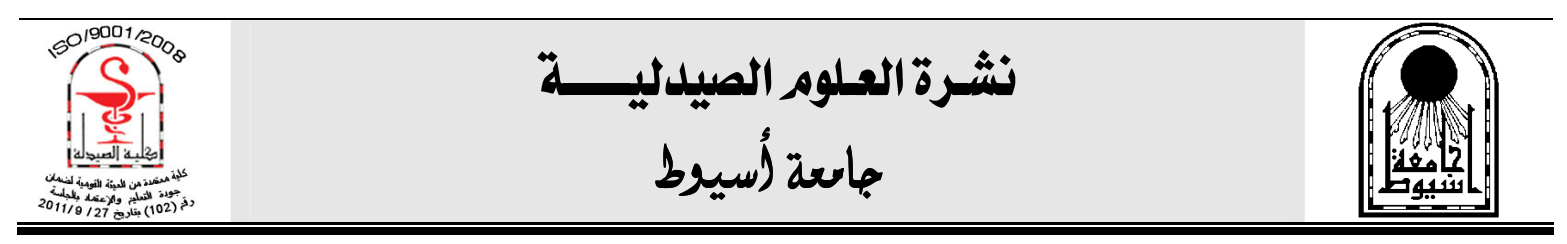

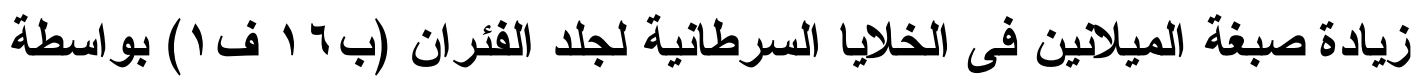

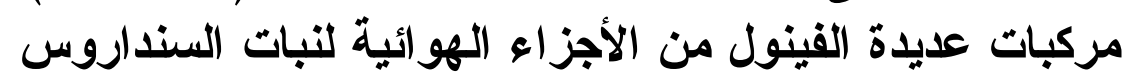

\author{
أحمد عز الدين عبد اللاه علام
}

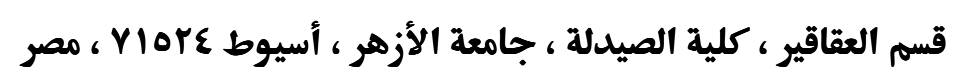

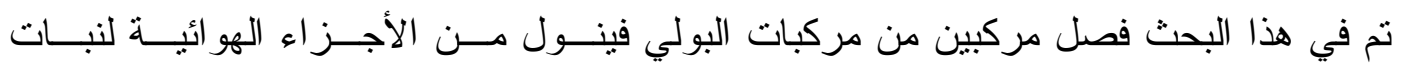

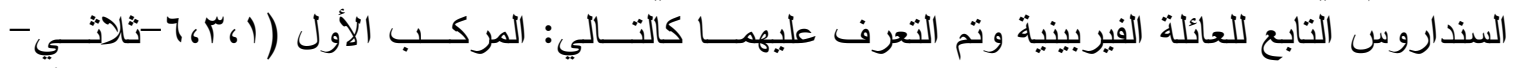

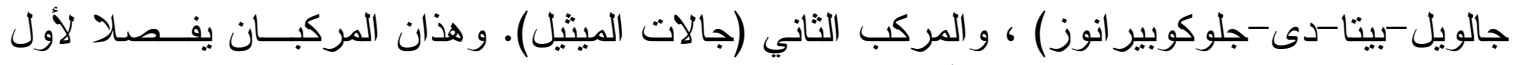

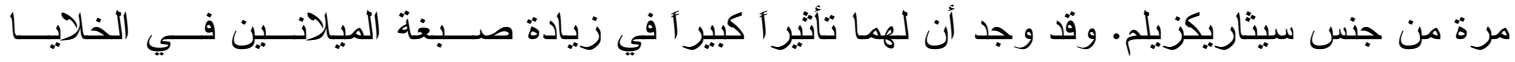

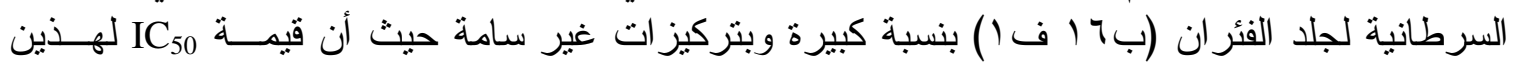

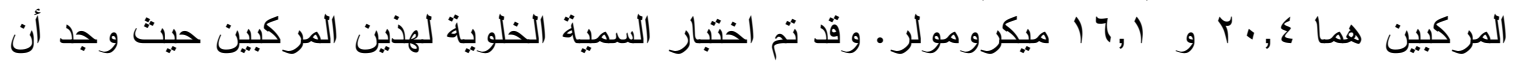

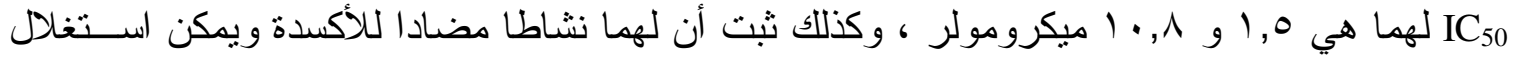

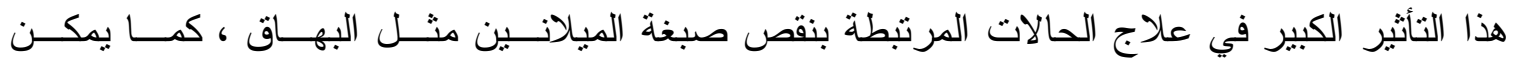
استخدامهما بأمان في الأغر اض النجميلية الات الأخرى. 